\title{
The Early Kimmeridgian succession at Kodrąb (Radomsko elevation, central Poland) and its palaeogeographical and palaeotectonic implications
}

\author{
Andrzej WIERZBOWSKI ${ }^{1, *}$ and Ewa GŁOWNIAK ${ }^{1}$
}

1 University of Warsaw, Institute of Geology, Faculty of Geology, Żwirki i Wigury 93, 02-089 Warszawa, Poland

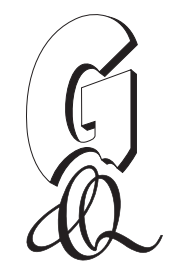

Wierzbowski, A., Głowniak, E., 2018. The Early Kimmeridgian succession at Kodrab (Radomsko elevation, central Poland) and its palaeogeographical and palaeotectonic implications. Geological Quarterly, 62 (3): 509-521, doi: 10.7306/gq.1421

The Early Kimmeridgian succession in the Rogaszyn Quarry at Kodrab (Radomsko elevation) represents mostly shallow-water carbonate platform deposits that, over wide areas of central Poland were controlled by the activity of the tectonic zone being the prolongation of the Holy Cross lineament. The ammonites collected enable precise recognition of ammonite zones the Platynota and the Hypselocyclum zones, some subzones and horizons. The precise dating enables detailed correlation of the particular units of the succession with those recognized at the eastern and northern borders of the Wielun Upland and the NW margin of the Holy Cross Mts. The deposits at Kodrab from the top of the Planula Zone, through the Platynota Zone, up to the lower part of the Hypselocyclum Zone, reveal markedly smaller thicknesses equaling $\sim 15-20 \%$ of those of coeval deposits from the adjoining areas. The differences in sedimentary evolution at Kodrab during the Early Kimmeridgian resulted mostly from local synsedimentary tectonic movements of fault blocks. Beginning from the late Hypselocyclum Chron, these differences markedly diminished, which resulted from the uniform subsidence of a wider area, and disappearance of the shallow-water deposits of the carbonate platforms, being replaced by deeper-water deposits of the Burzenin Formation.

Key words: Radomsko elevation, Early Kimmeridgian, ammonite stratigraphy, palaeogeography, synsedimentary tectonics.

\section{INTRODUCTION}

The Radomsko elevation is a Laramian structure where the Upper Jurassic deposits are brought to the surface in the cores of several folds, generally placed in the axis of the Łodż Synclinorium and the Miechów Synclinorium, and at the border between these two large tectonic units (Fig. 1). The southwestern part of the elevation, called the "Kodrab bolt" in older geological literature, is represented by two anticlines - the Chelm Anticline and the Smotryszów Anticline, where the Upper Jurassic deposits have been exposed and studied in the quarries (e.g., Łuniewski, 1947; Karczewski, 1965; Kutek, 1968). The Upper Jurassic deposits discussed herein include the succession seen in the Smotryszów Anticline, mostly in the Rogaszyn Quarry, near the village of Kodrab. Although the succession has been studied previously (Jaworowski, 1962; Karczewski, 1965; and especially Kutek, 1968), the current research gives the most comprehensive outline of its stratigraphy, resulting from a fairly large number of ammonites collected ( $>40$ specimens). Some of these ammonites have already been collected by J. Kutek. However, the essential part of the collection ( 25 specimens) was gathered in 1989 by the co-author (EG) who also studied the lithological succession, but these observations have not been published so far. On the other hand, after a long time of the quarry's abandon-

* Corresponding author, e-mail: andrzej.wierzbowski@uw.edu.pl Received: February 1, 2018; accepted: April 19, 2018; first published online: July 12, 2018 ment, the new owner cleaned some parts of the nearly fully overgrown old quarry in 2015-2017, which gave the opportunity to undertake the new study of the succession. This resulted in gathering of some new ammonites and new observations on the lithology of the succession by the other co-author (AW), which are presented in this study.

The formation of the Radomsko elevation during the Laramian tectonic movements was strictly related to the activity of deeply rooted fault zones, and resulted from its location at the crossing of the NW-SE-striking Poznań-Rzeszów lineament with the WNW-ESE-stretching northern border of the Małopolska Massif, corresponding to the Holy Cross lineament (see Pożaryski, 1971; Czubla, 1988). The continuation of the Laramian deformation related to the activity of the Holy Cross lineament towards the west, where it was affected by tectonic deformation of the Permo-Mesozoic basement of the Fore-Sudetic Monocline at the present northern border of the Wielun Upland, is also generally accepted (e.g., Głazek, 1999; Głazek et al., 2015). Such a tectonic position of the areas discussed resulted also in the successive development of several younger tectonic units during the Oligocene and Miocene, e.g. the Kleszczów Graben filled with Neogene brown coal deposits (e.g., Pożaryski, 1971; Mrozek, 1975). It should be remembered that the tectonic activity of some of these tectonic zones during sedimentation of the Late Jurassic deposits has also been proved. According to Matyja and Wierzbowski (2014) the progradation of the shallow-water carbonate platform during the Early Kimmeridgian onto the areas at the northern border of the Wielun Upland was controlled by tectonic activity of the Holy Cross lineament. The activity of the tectonic zone controlled also sedimentation during Late Oxfordian-Early Kimmeridgian 


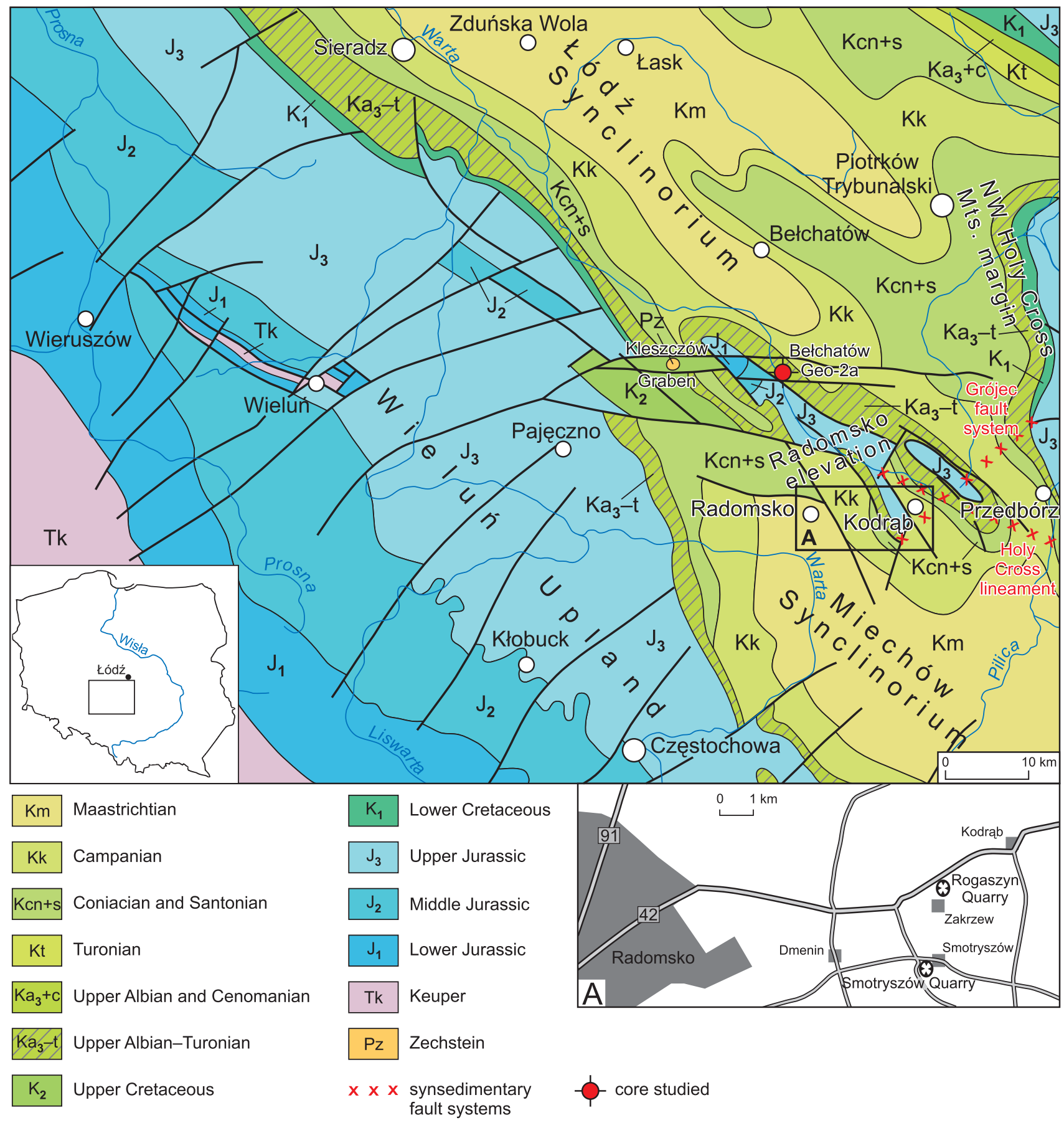

Fig. 1. Geological map (after Dadlez et al., 2000) showing the position of the Radomsko elevation in relation to other tectonic units discussed in this study. Location map (A) shows the position of the Rogaszyn Quarry and the Smotryszów Quarry in the Kodrąb area

at the so-called Złoczew and Bełchatów highs, where the distribution of the individual facies types in the underlying formations appear strictly related to the succeeding development of the younger graben structures in these areas (Krajewski et al., 2016). The same tectonic movements controlled also the facies pattern during the Early Kimmeridgian in the adjoining northern and eastern areas of the Wielun Upland (Wierzbowski, 2017). The special position of the area of study within the tectonic structure of the Radomsko elevation offers thus a possibility of study not only the stratigraphy of the well-detailed Early Kimmeridgian succession, but also the tectonic control on the formation of these deposits when compared with neighbouring areas.

\section{EARLY KIMMERIDGIAN SUCCESSION AT KODRĄB IN THE SMOTRYSZÓW ANTICLINE}

The succession begins with the so-called "chalky limestone complex" studied by Kutek (1968) in the old quarry at Smotryszów, showing the upper part of the complex, and attaining here $\sim 50 \mathrm{~m}$ in thickness (Fig. 2; but note that the uppermost part of the complex is depicted only). This part of the succession is represented by two chalky limestone units sandwiched by a thin packet of micritic limestones and oolites. The chalky limestones dominate in this part of the succession and are represented by 


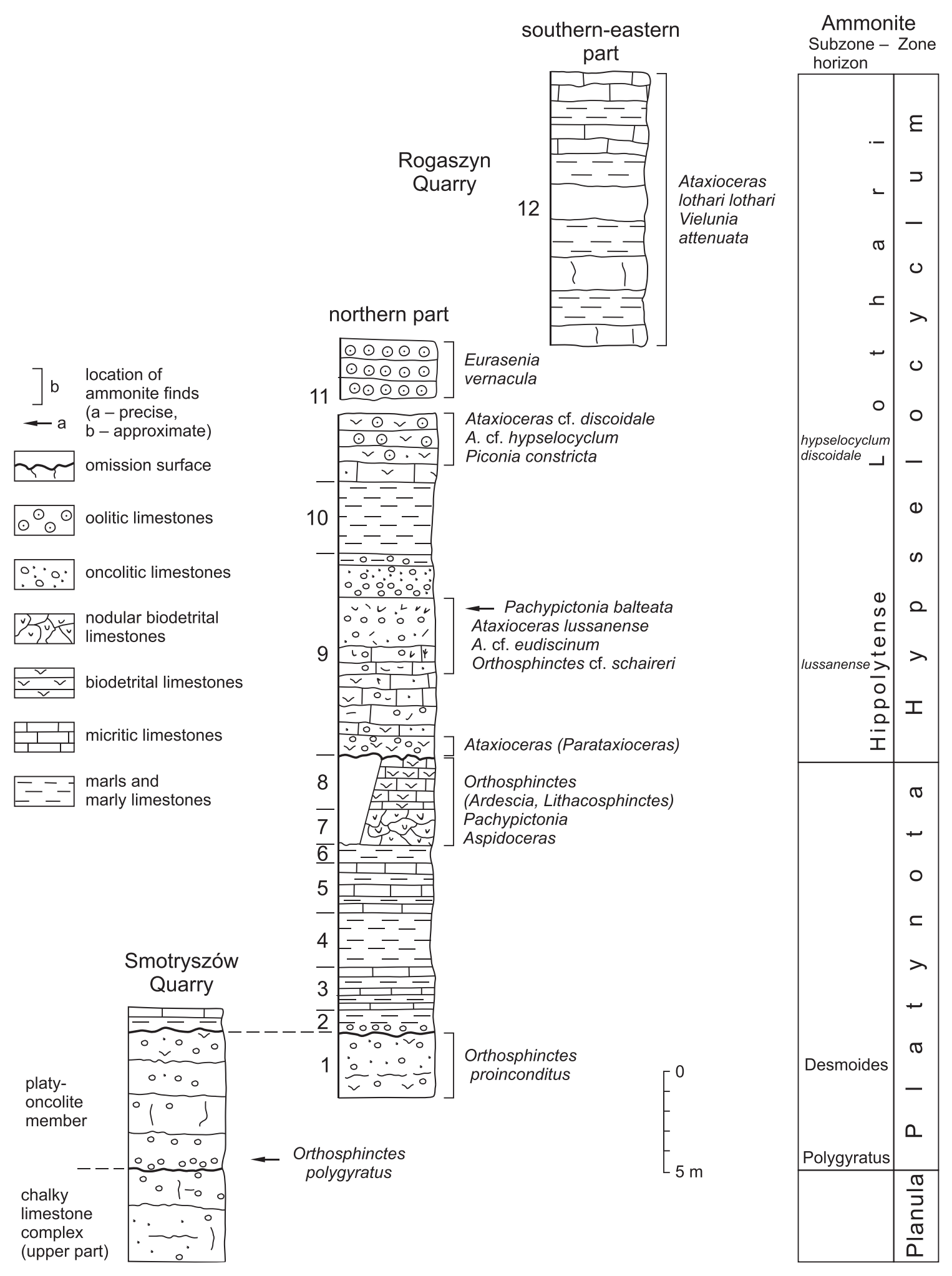

Fig. 2. The Lower Kimmeridgian succession at Kodrąb in the Smotryszów Quarry (after Kutek, 1968) and the Rogaszyn Quarry (studied herein); the most important ammonite finds are indicated, and their chronostratigraphical interpretation is given

The succession represents shallow-water deposits of the "oolitic formation" (units 1-11) strongly reduced in thickness as compared with coeval deposits at the borders of the Wielun Upland and the NW margin of the Holy Cross Mts. (cf. Table 1), and the overlying deposits of the Burzenin Fm. (unit 12) 
soft, friable limestones containing rich benthic fauna composed mostly of hermatypic corals, solenoporas, nerineid gastropods and thick-shelled bivalves (Diceras and a diverse oyster assemblage), and very common large oncoids in their topmost part (see Łuniewski, 1947; Karczewski, 1965; Kutek, 1968). These deposits have not yielded any ammonites, and their stratigraphical interpretation is based on younger ammonite finds directly above this unit (see below).

The directly younger deposits are seen both in the Smotryszów Quarry and in the Rogaszyn Quarry and these have been lumped by Kutek (1968) in a very widely treated "platy-oncolite member" that is, however, subdivided herein into several smaller rock units (Figs. 2 and 3). The oldest one is the oncolite limestone unit (unit 1) composed mostly of oncolites often developed around fragments of Nanogyra shells, and especially very common and densely packed in the lowermost part of the unit. These deposits may attain $~ 7-10 \mathrm{~m}$ in thickness, and they overlie the older deposits with an uneven, sharp boundary (Jaworowski, 1962). Two stratigraphically very important ammonite finds come from this unit. The older one is a celebrated specimen of Orthosphinctes, the oldest ammonite found so far in the outcrops of the Radomsko elevation area, coming from the Smotryszów Quarry from the lowermost part of the oncolitic limestone unit (Jaworowski, 1962; Kutek, 1968: pl. 1: 1; and illustrated herein in Fig. 4A), which is Orthosphinctes (Orthosphinctes) polygyratus (Reinecke) according to definition
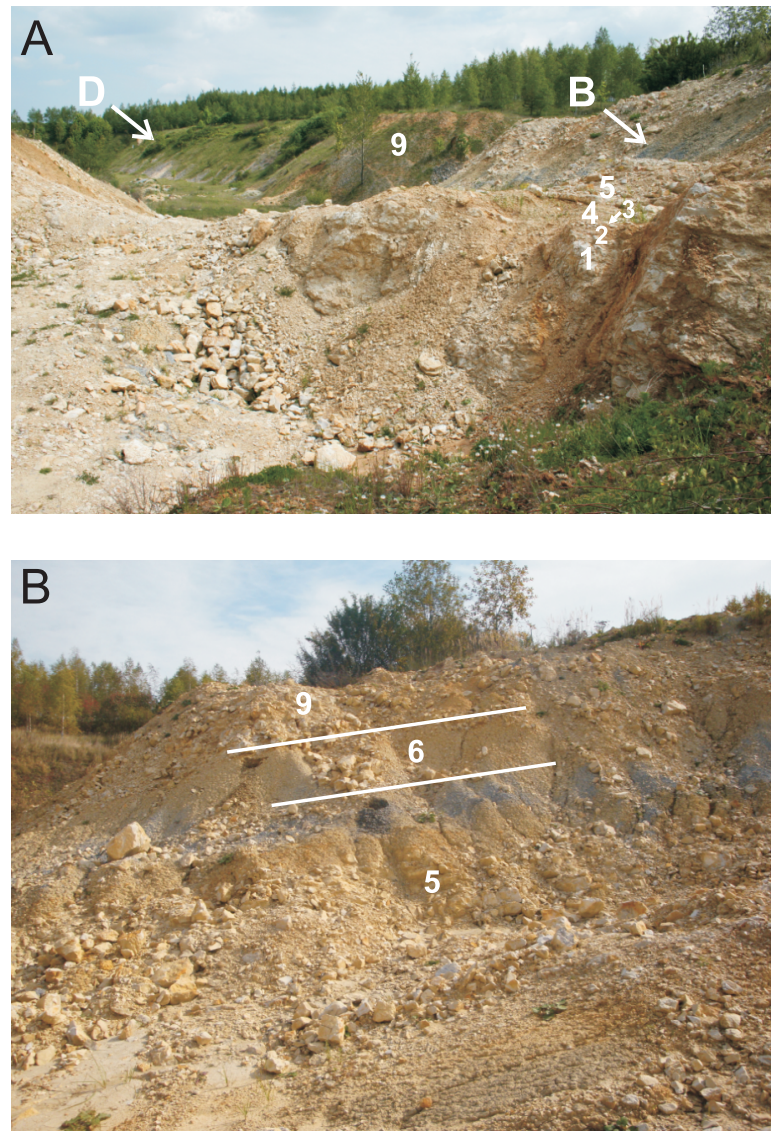

of the species given by Atrops (1982). This statement has important stratigraphical consequences because O. polygyratus is diagnostic for the uppermost part of the Planula Zone and the lower part of the Platynota Zone (see Atrops, 1982; see also Wierzbowski, 2017). The younger ammonite has been discovered recently in the rubble from the topmost part of the oncolite limestone unit 1, cropped out in the Rogaszyn Quarry, $\sim 3 \mathrm{~m}$ in thickness. The ammonite (Fig. 4B) is Orthosphinctes (Ardescia) proinconditus (Wegele) - see Atrops (1982: p. 91-96, pl.1: 1; pl. 20: 1-5). This species is characteristic of the Desmoides Subzone representing the middle part of the Platynota Subzone (Atrops, 1982). The occurrence of the two discussed ammonites in the oncolite limestone unit of the succession studied strongly suggests the correlation of this stratigraphical interval with the lower part (Galar to Polygyratus subzones, see Wierzbowski, 2017), and some middle part (Desmoides Subzone) of the Platynota Zone.

This stratigraphical interpretation is in general accordance with that given previously (Jaworowski, 1962; Kutek, 1968), according to which the deposits corresponding to the oncolite limestone unit in the Smotryszów Anticline have been correlated with the Platynota Zone. The crucial, however, is the location of the lower boundary of this zone. According to Kutek (1968) this boundary can run much lower in the succession, and the bulk of a very thick chalky limestone complex could belong in fact to the Platynota Zone. A similarly developed
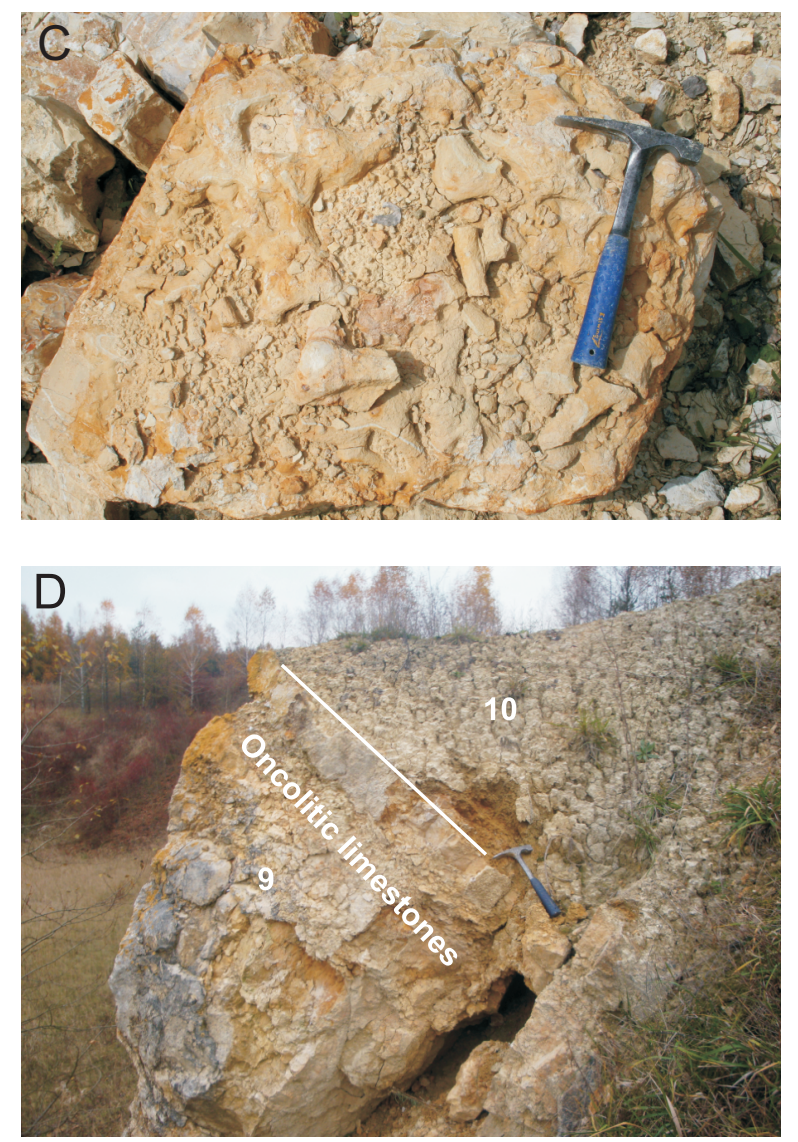

Fig. 3. Selected photos of the Rogaszyn Quarry (taken in 2017)

A - general view of the northern part of the quarry showing the position of the sections presented in Figures $B$ and $D$; in front, the continuous succession of units $1-5$ is seen; in background, partly overgrown unit 9; B - view over rock units $5-6$ overlain by unit 9 with the omission surface at its base; $\mathbf{C}$ - cast of the omission surface of the base of unit 9 with abundant Thalassinoides burrows; D - view over the upper part of unit 9 composed of oncolitic limestones, and overlying marls of unit 10 (the hammer is placed at the boundary) 

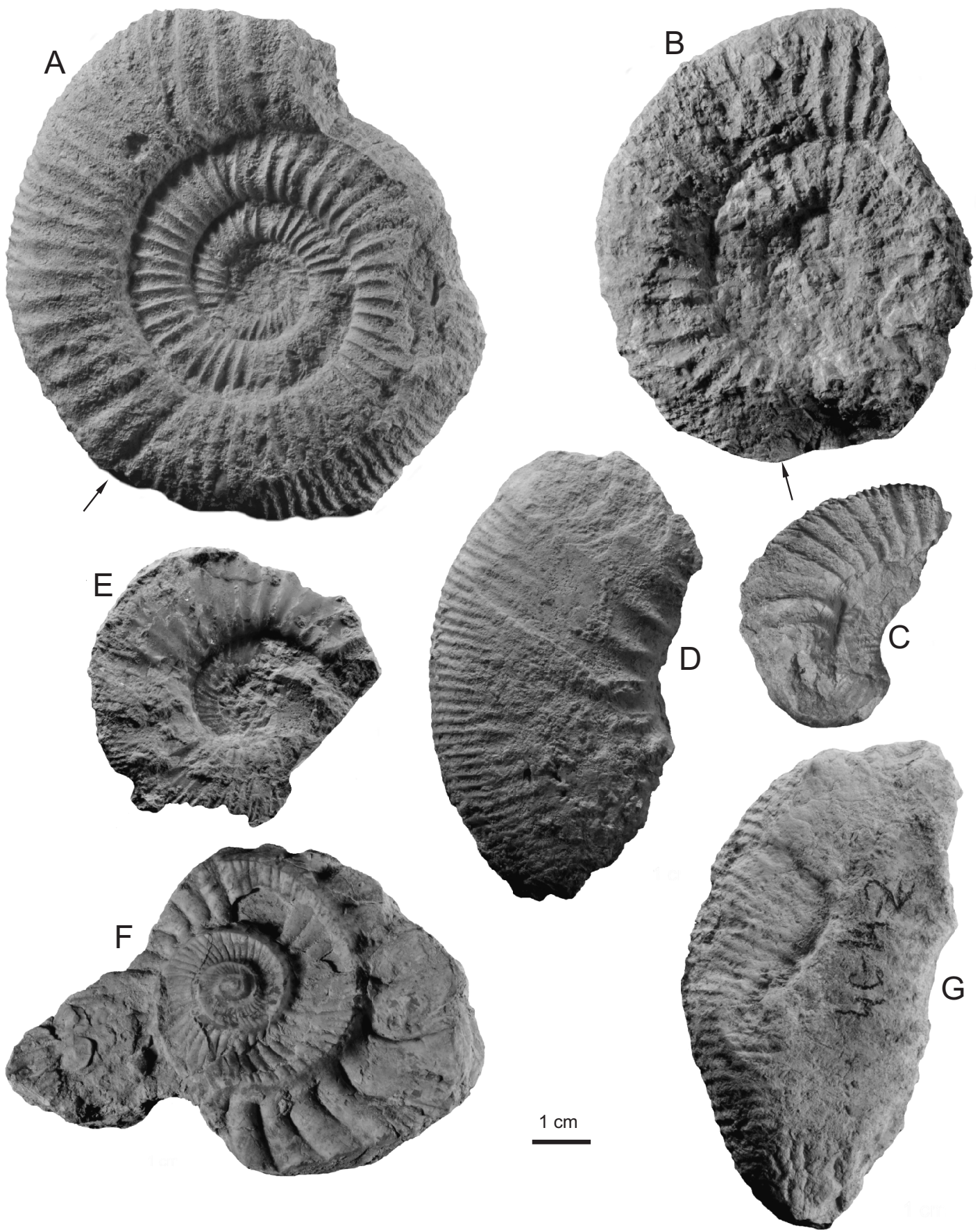

Fig. 4. Ammonites of the genera Orthosphinctes and Ataxioceras from the Rogaszyn and Smotryszów quarries

A - Orthosphinctes (Orthosphinctes) polygyratus (Reinecke) (= Perisphinctes (Orthosphinctes) pseudobreviceps Wegele in Kutek (1968: p. 1: 1); Smotryszów Quarry, platy-oncolite member of Kutek (1968), basal part, Platynota Zone, Polygyratus Subzone; MWG UW ZI/92/01; B - Orthosphinctes (Ardescia) proinconditus (Wegele); Rogaszyn Quarry, unit 1, upper part, rubble, Platynota Zone, Desmoides Subzone; MWG UW ZI/91/01; C - Orthosphinctes (Ardescia) cf. schaireri Atrops; fragment of outer whorl preserved is the body-chamber; Rogaszyn Quarry, unit 9, middle-upper parts, rubble, Hypselocyclum Zone, lussanense horizon; MWG UW ZI/91/10; D - Ataxioceras (Ataxioceras) cf. eudiscinum Schneid; phragmocone; Rogaszyn Quarry, unit 9, middle-upper parts, rubble, Hypselocyclum Zone, lussanense horizon; MWG UW ZI/91/02; E - Ataxioceras (Schneidia) lussanense Atrops; phragmocone; Rogaszyn Quarry, unit 9, middle-upper parts, rubble, Hypselocyclum Zone, lussanense horizon; MWG UW ZI/91/11; F - Ataxioceras (Schneidia) Iussanense Atrops; external mould; Rogaszyn Quarry, unit 9, middle-upper parts, rubble, Hypselocyclum Zone, lussanense horizon; MWG UW ZI/91/09; G - Ataxioceras (Ataxioceras) cf. discoidale Schneid; phragmocone; Rogaszyn Quarry, unit 11 (Oolite of Smotryszów), Hypselocyclum Zone, discoidale horizon; MWG UW ZI/91/16; the phragmocone/body-chamber boundary is arrowed 
succession of the chalky limestones in the southwestern border of the Holy Cross Mts. is covered by deposits recognized by Kutek (1968) as the "deposits overlying chalky limestones" developed as micritic limestones with marly intercalations sandwiched by the oolitic limestones. The basal part of these deposits yielded some ammonites similar to those described above, such as Orthosphinctes (Orthosphinctes) polygyratus (Reinecke), and O. (Lithacosphinctes) gidoni Atrops indicative of the uppermost Planula/lower Platynota Zone boundary (Gutowski et al., 2006), whereas the not numerous ammonites found below in the chalky limestones indicated either the Planula Zone or were not conclusive for recognition of the detailed stratigraphical position of the deposits (see Kutek, 1968). This suggests that the upper boundary of the chalky limestone deposits in both the Radomsko elevation area and the SW margin of the Holy Cross Mts. marks the sudden change in the sedimentary succession commented further in the paper, and is placed close to the Planula/Platynota Zone boundary (see also chapter on correlations).

The younger deposits, cropping out in the Rogaszyn Quarry in the Smotryszów Anticline, and studied recently (AW), include the following rock units (see Figs. 2 and $3 A$; coordinates of the base of the section are: N $51^{\circ} 05^{\prime} 15.9^{\prime \prime}$, E $19^{\circ} 36^{\prime} 07.2^{\prime \prime}$; bed position $-135 / 25 \mathrm{~N}$ ): unit 2 - marls containing numerous oncolites, $\sim 1.10 \mathrm{~m}$ in thickness; unit 3 - bedded micritic limestones of mudstone type with marly intercalations (thickness of limestone beds oscillates between 0.08 and $0.25 \mathrm{~m}$, thickness of marly layers attains $5-8 \mathrm{~cm}$ ) - thickness of the whole unit is $\sim 2.20 \mathrm{~m}$; unit 4 - blue-grey marls with subordinate and thin marly limestone intercalations, thickness $\sim 2.60 \mathrm{~m}$; unit 5 - bedded micritic limestones of mudstone type with marly intercalations similar to those of unit 3 - thickness $\sim 2.30 \mathrm{~m}$; unit 6 - grey marls with intercalations of marly limestones, $\sim 1 \mathrm{~m}$ in thickness; at the top of marls is the well-developed omission surface with common Thalassinoides burrows (Fig. 3B, C). Younger deposits are developed possibly only locally. These include the nodular biodetrital limestones, heavily bioturbated, $\sim 2 \mathrm{~m}$ in thickness (unit 7 ), and the overlying well-bedded micritic limestones with abundant small bioclasts, $\sim 3 \mathrm{~m}$ in thickness (unit 8), at the top with an omission surface similar in character to that at the top of unit 6 . These deposits were observed by the co-author (EG) in the northern part of the Rogaszyn Quarry, some tens of metres north from the section described above, where they occurred in stratigraphical continuity above units 1-6. It is difficult to prove unequivocally, because of the poor condition of the exposure of this part of the succession in the Rogaszyn Quarry nowadays, if the omission surface at the top of unit 6 is the same surface as that of unit 8 , but such an assumption seems very likely. This may indicate that there is only one eminent omission surface cutting unconformably the underlying deposits. The deposits of units 7-8, directly underlying the omission surface, yielded several ammonites, found mostly in the rubble. They are commonly filled with biodetrital micritic matrix, but some of them are heavily overgrown on both sides by Nanogyra oysters, showing thus their local redeposition. These ammonites include: Orthosphinctes (Ardescia) sp., O. (Lithacosphinctes) sp., large Pachypictonia sp., and the only representative of Aspidoceratidae found in the quarry - Aspidoceras $\mathrm{sp}$., indicating the stratigraphical interval from the Platynota Zone to the lowermost part of the Hypselocyclum Zone, but most likely close to the Platynota/Hypselocyclum zone boundary as proved by the common occurrence of Orthosphinctes and lack of Ataxioceras (see Atrops, 1982).

Part of all these deposits were known to Kutek (1968: fig. 13) who recognized probably only their lowermost part that outcrops in the Smotryszów Quarry, but the bulk of them in the
Rogaszyn Quarry, including the eminent omission surface, became unknown to him.

The deposits overlying the omission surface in the Rogaszyn Quarry section are biodetrital limestones (wackestone to packstone) with common fragments of oyster shells, and massive shell bivalves (Trichites) (lowermost part of unit 9 , $\sim 1 \mathrm{~m}$ in thickness). A single poorly preserved ammonite fragment found here belongs to Ataxioceras (Parataxioceras) sp. Its fragmentary preservation disables unequivocal species identification; however, being similar to A. homalinum Schneid, it suggests the basal part of the Hypselocyclum Zone.

The younger deposits in the Rogaszyn Quarry are currently poorly exposed and seen mostly in the rubble. They were better exposed and studied in detail in the past (co-author EG). These deposits (Figs. 2 and 3A, D), corresponding to the bulk of unit 9 , $\sim 7 \mathrm{~m}$ in thickness, are cream-coloured limestones (wackestone to packstone) with common bioclasts and loosely distributed small oncoids and ooids; they often show indistinct trend to split into thin flags with irregularly developed surfaces. A marked level with abundant oncolites occurs $\sim 2 \mathrm{~m}$ below their top. The fauna is very common and represented mostly by a diverse assemblage of bivalves - from infaunal to semiinfaunal, epibyssate and to the recline and cementing forms (Pholadomya, Pleuromya, Cercomya, Inoperna, Astarte, Lima, Mytilus, Trichites, Nanogyra). It also includes free-swimming pectinids, as well as gastropods (mostly of the family Nerineidae) and brachiopods - both terebratulids and rhynchonellids (see Karczewski, 1965: pl. 4-12). These deposits correspond possibly to beds 15-17 of Kutek (1968: fig. 13). The ammonites occur fairly commonly in the middle-upper parts of the unit (25 collected specimens). Especially numerous Ataxioceratinae ( $80 \%$ of the total number of specimens) were found here: Ataxioceras (Schneidia) lussanense Atrops - occurring the most commonly (Fig. 4E, F), beside Orthosphinctes (Ardescia) cf. schaireri Atrops (Fig. 4C), Ataxioceras (Ataxioceras) cf. eudiscinum Schneid (Fig. 4D), and Ataxioceras (Parataxioceras) sp., as well as some specimens mentioned and/or illustrated previously: "Perisphinctes" sp. in Karczewski (1965: pl. 12: 4), which is Orthosphinctes (Ardescia) possibly close to O. (A.) inconditus (Fontannes), and Ataxioceras sp. (Kutek, 1968). The overall character of these ammonites enables very precise dating of the deposits as corresponding to the basal part of the Hypselocyclum Zone, and the Hippolytense Subzone - i.e. to the lussanense horizon as established by Atrops (1982). The same deposits also yielded some representatives of Aulacostephanidae: Pachypictonia balteata (Schneid) (Fig. 5C, D), Involuticeras involutum (Quenstedt) (Kutek, 1968), and poorly preserved fragments that can be attributed to Pachypictonia and/or Pictonia (Pictonites).

The topmost deposits of unit 9 are well-exposed in the northern part of the Rogaszyn Quarry (N 510.'22.1', E $\left.19^{\circ} 36^{\prime} 11.3^{\prime \prime}\right)$, in the upper part of the section (Fig. 3D). These are the massive oncolitic limestones with closely packed large oncoids in its lower part ( $0.8 \mathrm{~m}$ thick bed), and small oncoids in abundant micritic matrix above $(0.8 \mathrm{~m}$ thick bed). They are covered by marly oncolite (bed $0.6 \mathrm{~m}$ thick), at the top with a thin bed ( $0.1 \mathrm{~m}$ thick) of micritic limestone with bivalve fauna. These deposits possibly correspond to beds 18-22 of Kutek (1968: fig. 13). They did not yield any ammonites.

The overlying deposits are yellowish brittle marls, $\sim 3.5 \mathrm{~m}$ in thickness (Fig. 3D), constituting unit 10, and these correspond, at least partly, to beds 23-25 of Kutek (1968: fig. 13). All these deposits, corresponding to units 1-10, can be correlated with the "platy-oncolite member" of Kutek (1968: kponk in fig. 11; see also fig. 12). 

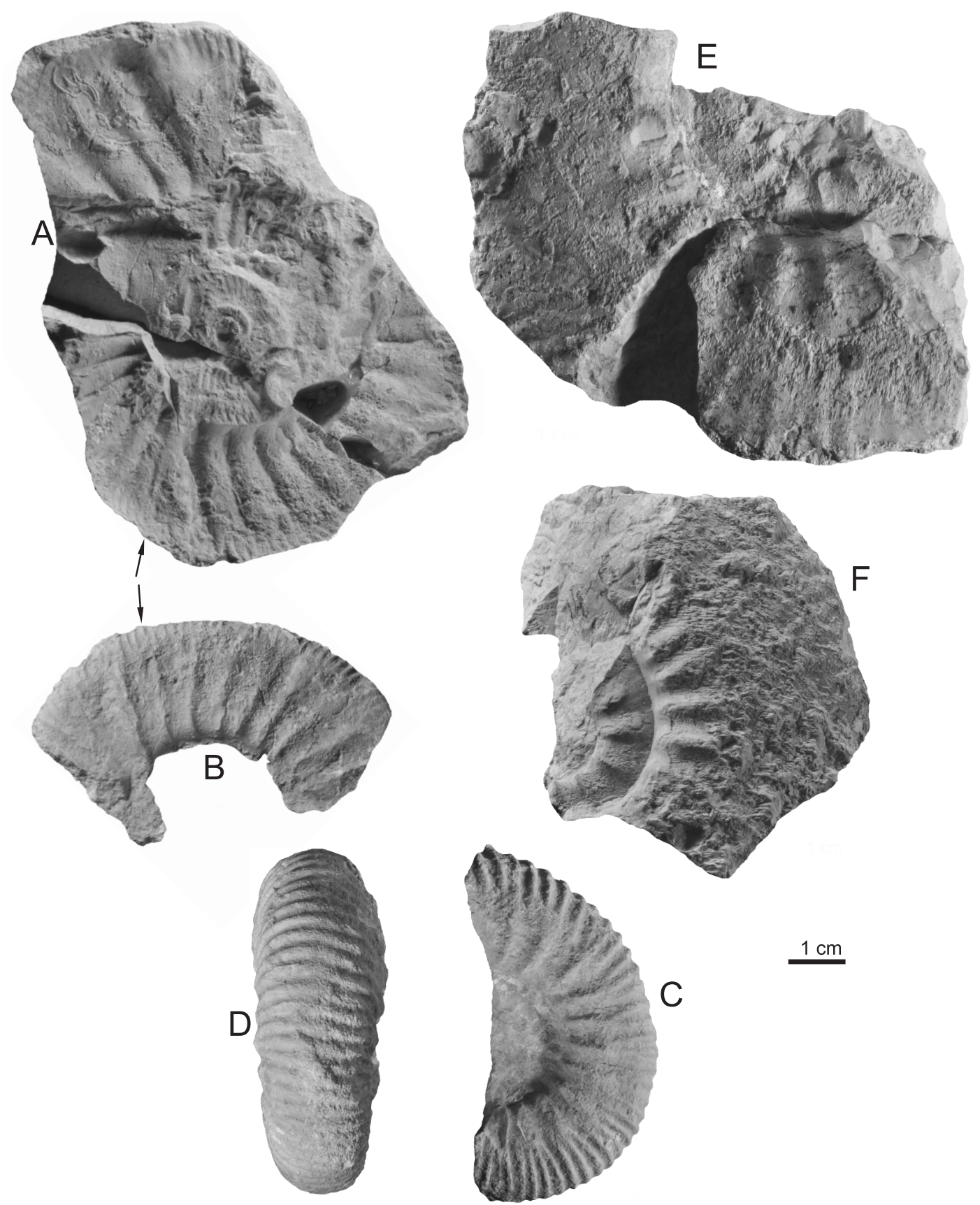

Fig. 5. Ammonites of the genera Ataxioceras, Pachypictonia and Eurasenia from the Rogaszyn Quarry

A, B - Ataxioceras (Parataxioceras) lothari lothari (Oppel); A - external mould; B - whorl fragment placed at the original position in relation to external mould; Rogaszyn Quarry, micritic limestones (unit 12), rubble, Hypselocyclum Zone, Lothari Subzone; MWG UW ZI/91/17; C, D - Pachypictonia balteata (Schneid); lateral view and ventral view; Rogaszyn Quarry, bed 9, upper part, Hypselocyclum Zone, lussanense horizon; MWG UW ZI/91/21;

E, F - Eurasenia cf. pendula (Schneid); phragmocone, both sides of the same specimen; Rogaszyn Quarry, unit 11 (Oolite of Smotryszów), Hypselocyclum Zone, discoidale horizon; MWG UW ZI/91/24; the phragmocone/body-chamber boundary is arrowed

The youngest deposits in the northern part of the quarry are hard micritic limestones, overlain by biodetrital and oolitic limestones of unit 11 . While studied by one of the authors (EG), only their lower part was exposed, $\sim 3-4 \mathrm{~m}$ in thickness. These deposits yielded some ammonites: Ataxioceras (Ataxioceras) cf. discoidale Schneid (Fig. 4G), A. (A.) cf. hypselocyclum (Fontannes), A. (Parataxioceras) sp., E. cf. pendula (Schneid) (Fig. 5E, F), and Pictonia constricta Schneid (Fig. 6). The oolitic lime- stones, exposed in the past in small quarries east of the Rogaszyn Quarry, possibly belong to some upper parts of this unit: they were known to Kutek (1968) who called them the "Oolite of Smotryszów" and described some ammonites found therein: Eurasenia vernacula (Schneid) (see Kutek, 1968: pl. 6: 6), Prorasenia quenstedti (Schindewolf) (see Kutek, 1968: pl. 6: 3) and Pictonia constricta Schneid (see Kutek, 1968: pl. 1: 3). The ammonite assemblage found in the oolites indicates the 


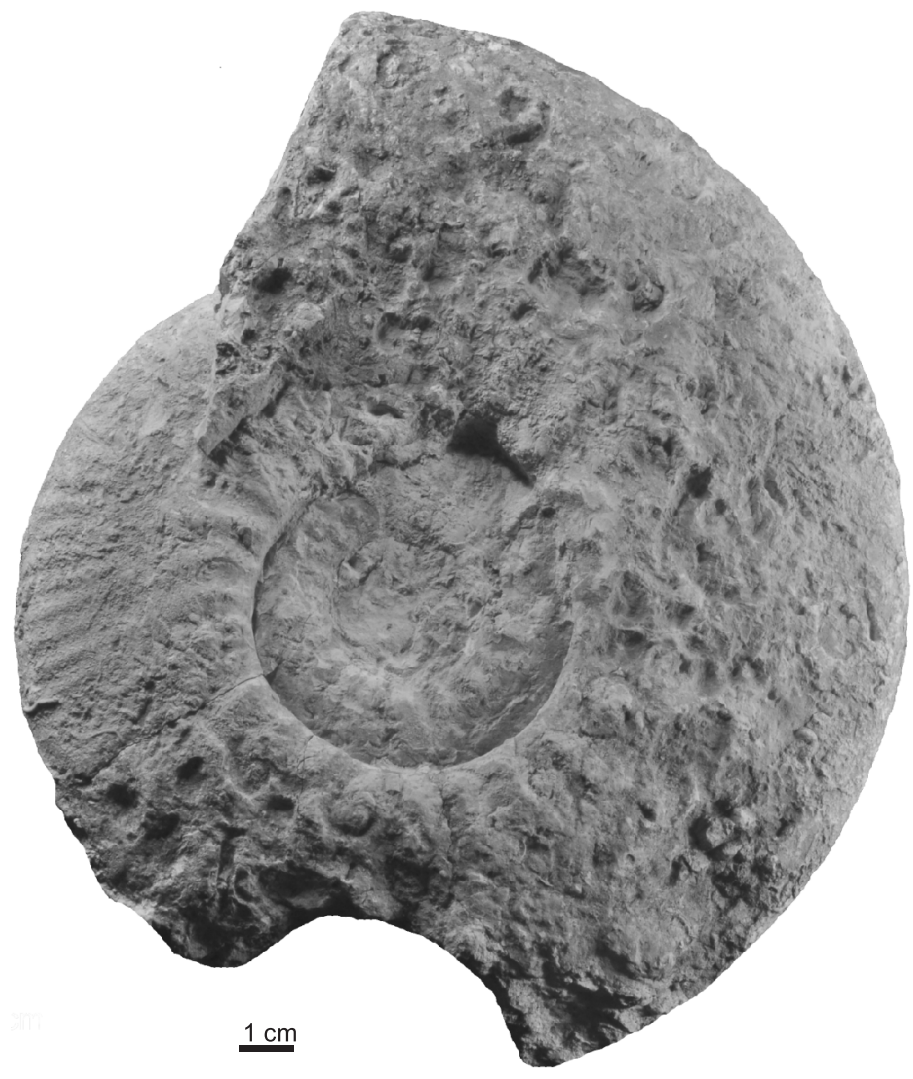

Fig. 6. Pictonia (Pictonites) constricta Schneid; phragmocone; Rogaszyn Quarry, unit 11 (Oolite of Smotryszów), Hypselocyclum Zone, discoidale horizon; MWG UW ZI/91/22

presence of the lower part of the Lothari Subzone of the Hypselocyclum Zone - most precisely the discoidale horizon up to the boundary with the hypselocyclum horizon (see Atrops, 1982; see also Wierzbowski, 2017).

The younger deposits of the succession are seen in the mostly overgrown southeastern part of the Rogaszyn Quarry (Fig. 2). These are well-bedded micritic limestones and marls of unit 12. The direct contact of these deposits with the above-described succession is not visible. The contact is possibly of tectonic nature because of the occurrence of a strike-parallel fault in the eastern limb of the Smotryszów Anticline, which brings the younger deposits to the surface (see Czubla, 1988: fig. 2). Some ammonites from the micritic limestones collected in the rubble in the Rogaszyn Quarry likely come from these deposits. Ataxioceras (Parataxioceras) lothari lothari (Oppel) (Fig. 5A, B) and some fragments of Ataxioceratinae were found here, including a specimen of Ataxioceras (Ataxioceras) sp., which indicates the presence of some lower-middle parts of the Lothari Subzone of the Hypselocyclum Zone (see Atrops, 1982; Wierzbowski, 2017). Aulacostephanidae are represented here by Vielunia attenuata (Schneid) (Fig. 7). These deposits may be correlated with some parts of the "platy limestones and underlying clays of Dmenin" of Kutek (1968), known from the western limb of the Smotryszów Anticline (see below).

The younger Upper Jurassic deposits were, however, most completely cropped out in the past in the western limb of the Smotryszów Anticline in the so-called Dmenin ridge (Łuniewski, 1947; Jaworowski, 1962; Kutek, 1968). These include the oncolitic limestones, at least $10 \mathrm{~m}$ in thickness, called the "Oncolite of Dmenin" (Kutek, 1968: onk D in fig. 11), and the overlying "platy limestones and underlying clays of Dmenin", $\sim 50 \mathrm{~m}$ in thickness (Kutek, 1968: wpi D in fig. 11). The Upper Jurassic succession of the Smotryszów Anticline is closed by thick marly deposits with intercalations of micritic limestones and Nanogyra coquinas, attaining $\sim 60 \mathrm{~m}$ in thickness, and referred to as "top clays of Dmenin" by Kutek (1968: is $D$ in fig. 11). Their stratigraphical position corresponds possibly to the upper part of the Lower Kimmeridgian (maybe also the lowermost Upper Kimmeridgian), although the ammonites are rare and poorly preserved (Jaworowski, 1962; Kutek, 1968). They are covered by Albian sandstones.

\section{AMMONITE PALAEONTOLOGY}

Below, we provide some palaeontological comments on the poorly known and/or especially stratigraphically important finds. The following abbreviations are used in descriptions: D - diameter of specimen in $\mathrm{mm}$; Wh - whorl height as a percentage of $\mathrm{D}$; $\mathrm{Ud}$ - umbilical diameter as a percentage of D; SR/PR - secondary/primary ribs ratio counted on 5 primary ribs at given diameter. The specimens studied are housed at the Museum of the Faculty of Geology, University of Warsaw (old collection of J. Kutek from the Radomsko elevation, partly described by Kutek (1968), along with other ammonites coming from the SW border of the Holy Cross Mts. - collection No. MWG UW ZI/92/01-07; new collection of Ewa Głowniak and Andrzej Wierzbowski MWG UW ZI/91/01-32 from the Rogaszyn Quarry).

Special attention should be paid to a specimen of the genus Orthosphinctes compared originally with "Perisphinctes (Orthosphinctes) pseudobreviceps (Wegele)" by Jaworowski (1962) and Kutek (1968: pl. 1: 1; and illustrated herein in Fig. 4A). The form Perisphinctes (Orthosphinctes) pseudobreviceps (Wegele) has been recognized successively as very close or even synonymous with Orthosphinctes (Orthosphinctes) polygyratus (Reinecke) (see e.g., Schairer, 1974). The overall character (coiling, type of ribbing) of the specimen clearly indicates its affinity with the species Orthosphinctes (Orthosphinctes) polygyratus (Reinecke) as revised by Atrops (1982). Another Orthosphinctes ammonite (Fig. 4B) shows the very evolute coiling and the moderately dense ribbing of the outer whorl (PR $=35$ at $D=80 \mathrm{~mm}$ ) with the characteristic dischizotomous subdivision of ribs and the high secondary/primary ribs ratio (SR/PR is $\sim 3.0$ at $D=80 \mathrm{~mm}$; these features indicate its close affinity with Orthosphinctes (Ardescia) proinconditus (Wegele) - see Atrops (1982: p. 91-96, pl. 1: 1; pl. 20: 1-5). A still younger specimen of the genus Orthosphinctes is a fragment of whorls (Fig. 4C), $40 \mathrm{~mm}$ in diameter, showing a wide peristomal constriction, the dense ribbing of the inner whorls, the rectiradiate whorl section, and the markedly prorsiradiate course of the secondary ribs. All these features indicate close affinity of the specimen with Orthosphinctes (Ardescia) schaireri Atrops (see Atrops, 1982: p. 97-102, pl. 4: 3-4, pl. 6: 12; pl. 28: 2-3).

Among the ammonites of the genus Ataxioceras the most numerous and stratigraphically important are undoubtedly specimens of Ataxioceras (Schneidia) lussanense Atrops. The specimens (Fig. 4E, F) are $\sim 60-80 \mathrm{~mm}$ in final diameter, densely ribbed in the inner whorls ( $P R=35-40$ ), and more loosely spaced thereafter, showing the low appearance of secondary ribs on the whorl height, and the involute coiling of inner 


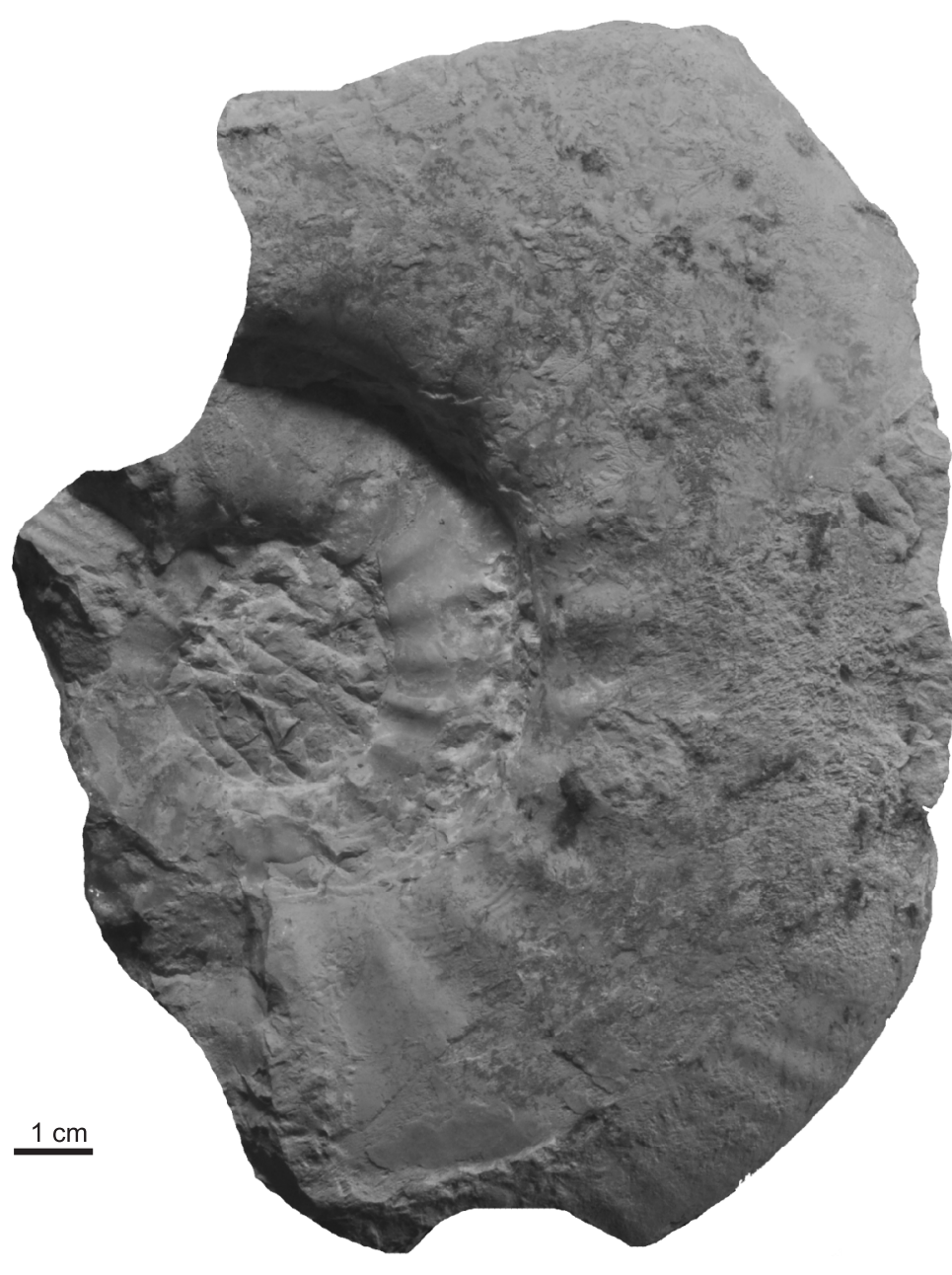

Fig. 7. Vielunia attenuata (Schneid); phragmocone; Rogaszyn Quarry, micritic limestones (unit 12), rubble, Hypselocyclum Zone, Lothari Subzone; MWG UW ZI/91/23

whorls. Another specimen (Fig. 4G) referred to as Ataxioceras (Ataxioceras) cf. discoidale Schneid is a fragment of the phragmocone, showing strongly developed ribs at the umbilicus, the lower polyplocoidal subdivision of ribs, and lack of constrictions. The fairly large imprint of another large specimen (Fig. 5A, B; 95-100 mm in final diameter) shows evolute coiling $(\mathrm{Wh}=35, \mathrm{Ud}=42$, at $\mathrm{D}=96 \mathrm{~mm})$; the ribbing of inner whorls is dense, but on the outer whorl the ribs are more loosely spaced $(P R=30)$, and the final constriction is partly preserved. This specimen can be safely compared with Ataxioceras (Parataxioceras) lothari lothari (Oppel) as revised by Atrops (1982: p. 198-206).

Pachypictonia balteata (Schneid) of the family Aulacostephanidae needs some comments on its taxonomical status (Fig. 5C, D). The species was attributed by Geyer (1961: p. 93) with some hesitation to the genus/subgenus Eurasenia, although its ornamentation and coiling are very close to those of the genus Pachypictonia (cf. Schneid, 1939, 1940). Another specimen, $\sim 200 \mathrm{~mm}$ in diameter (Fig. 6), represents the phragmocone with ornamentation similar to that of the inner whorls of generally smaller Pictonia constricta Schneid, and possibly conspecific $P$. tereticornis Schneid (see Schneid, 1940: p. 105, pl. 14: 1-3; p. 106, pl. 13: 3 and 14: 4; see also Geyer, 1961: p. 115). This specimen is close to that described recently by Wierzbowski (2017: pl. 9: 1ab), and both of them, although differing in the final size from the bulk of described so far specimens of $P$. constricta, can be, however, easily accommodated in that species because of similarity in ornamentation. In the youngest deposits of the succession studied in the Rogaszyn Quarry, a large specimen has also been found (Fig. 7), $200 \mathrm{~mm}$ across, representing the phragmocone: it shows the presence of the moderately thick, relatively long primary ribs, and similarly developed the secondary ribs. The ribbing of the outer whorl of the phragmocone reveals the presence of the swollen primary ribs at the umbilicus, whereas the rest of the whorl becomes smooth. This specimen can be safely compared with the large specimen of "Pictonia attenuata" of Schneid (1940: p. 106-107, pl. 10: $6-7)$, which may be recognized as the lectotype of the species. According to its ornamentation it should be compared with the genus Vielunia and treated as one of the youngest form of the genus Vielunia attenuata (Schneid).

\section{COMPARISON WITH NEIGHBOURING AREAS AND SYNSEDIMENTARY TECTONICS}

The deposits outcropped at Kodrab can be easily compared with coeval deposits known from the adjoining areas, especially from the eastern and northern borders of the Wielun Upland (Wierzbowski, 2017) which is part of the Silesian-Cracow Monocline, and the northwestern border (Tomaszów Syncline) of the Holy Cross Mts. (Matyja and Wierzbowski, 2014). Additionally, the deposits are comparable with a succession from the Bełchatów Geo-2a borehole drilled in the northernmost part of the Łękińsko Anticline, being the northern prolongation of the Smotryszów Anticline of the Radomsko elevation (see Pożaryski, 1971; Mrozek, 1975). The succession was studied by the co-author (AW) already during the late 1960 s and still remains unpublished. The comparison of the deposits studied at Kodrab with those of the neighbouring areas can be given both on their facies characteristics and precisely established stratigraphical position as based on the ammonite fauna. Helpful in this study is also tracing the position of the main marly units in all the successions studied, which appears almost isochronous over the large areas (Wierzbowski, 1966, 2017). Such an approach enables additionally the recognition of the differences in the thickness of the coeval deposits between the particular regions, which is of the crucial importance for the identification of synsedimentary tectonics (Table 1).

The sections from the chalky limestone complex below to the Oolite of Smotryszów above, and possibly even still higher up to the "Oncolite of Dmenin" of the Kodrab succession, represent shallow-water deposits, the correlation of which with the informally distinguished "oolitic formation" of Dembowska (1979) is herein accepted. The oldest of them is the chalky limestone complex with corals, solenoporas and nerineid gastropods, and intercalations of oolites, cropping out at Smotryszów where its topmost part seen in the quarry attained $\sim 50 \mathrm{~m}$ in thickness (Kutek, 1968). These deposits may be correlated with the limestones of the "coral formation" (according to Dembowska, 1979) in the northwestern border of the Holy Cross Mts. reaching at least $100 \mathrm{~m}$ in thickness there (Matyja and Wierzbowski, 2014). Similar deposits with nerineids and admixture of oolites, 
Summary of lithostratigraphic formations and members at the borders of the Wielun Upland (after Wierzbowski, 2017), Radomsko elevation (as described herein) and NW margin of the Holy Cross Mts.

(Tomaszów Syncline) (after Matyja and Wierzbowski, 2014), showing the differences in thickness of the coeval deposits between the particular areas

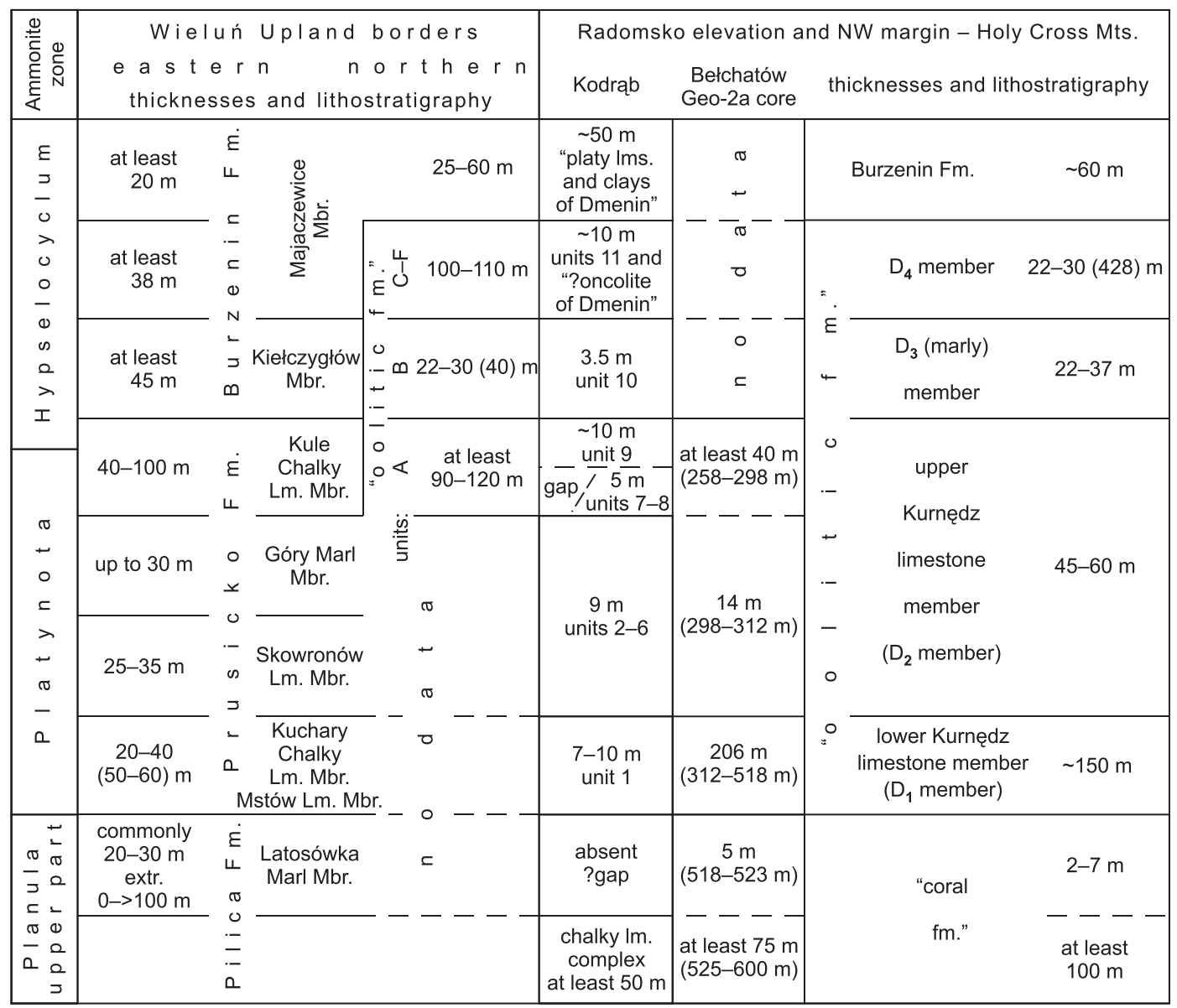

recognized in the Bełchatów Geo-2a core, are at least $\sim 75 \mathrm{~m}$ in thickness (depth 525-600 m). The overlying deposits are marls and marly limestones, attaining from $\sim 2-3$ to $7 \mathrm{~m}$ in thickness at the northwestern border of the Holy Cross Mts. (Matyja and Wierzbowski, 2014), and $5 \mathrm{~m}$ in thickness in the Bełchatów Geo-2a core (depth 518-523 m), but missing at Kodrab, which suggests a stratigraphical gap at the top of the chalky limestone complex in the succession. These marly deposits may be correlated with the so-called "lower marly unit" of Wierzbowski (1966), which represents the Latosówka Marl Member of the upper part of the Pilica Formation. They may be attributed to the topmost part of the Planula Zone - the upper part of the ammonite minutum horizon (Wierzbowski, 2017).

The younger deposits of the Kodrab succession reveal a very special facies development generally characterized by a very small thickness of rock units when compared with that of the neighbouring areas. It begins with the oncolitic limestones (unit 1, Fig. 2), only $\sim 7-10 \mathrm{~m}$ in thickness, which yielded ammonites of the lower and some middle parts of the Platynota Zone, indicating their correlation with the Mstów Limestone Member and the Kuchary Chalky Limestone Member of the lower part of the Prusicko Formation at the eastern border of the Wielun Upland. These members represented by the chalky limestones with sponges, brachiopods and rare corals Microsolenidae, and the micritic limestones of mudstone type attain fairly large thickness usually between $20-40 \mathrm{~m}$ (but locally ranging up to $50-60 \mathrm{~m}$ ) at the Wieluń Upland. The coeval deposits at the northwestern border of the Holy Cross Mts., belong to the "oolitic formation". They consist of chalky limestones with corals, nerineid gastropods and oysters, locally with intercalations of oolitic limestones, and are distinguished as the "lower Kurnędz limestone member" or $D_{1}$ member and show even a greater thickness up to $\sim 150 \mathrm{~m}$ (see Matyja and Wierzbowski, 2014). The same trend is observed in the Bełchatów Geo-2a borehole where the corresponding deposits containing abundant shallow-water organisms (corals, nerineid gastropods, solenoporas) are $\sim 200 \mathrm{~m}$ thick (depth $312-518 \mathrm{~m}$ ). It should be remembered that the Prusicko Formation is interpreted as representing a moderately shallow marine environment (although deeper than that of the "oolitic formation"), deposited below the wave base, which appeared after the dominance of the deeper-water environment of the sponge megafacies and related deposits (Czestochowa Limestone Fm., Pilica Fm.) in the Wielun Upland and its eastern border areas. Its lateral equivalent was the "oolitic formation" which originated due to progradation of the shallow-water carbonate platform towards the west onto the 
area at the northern border of the Wielun Upland (Wierzbowski, 2017). Thus, the difference in thickness between the discussed carbonate deposits of the "oolitic formation" and those of the Prusicko Formation resulted obviously from the position of the areas of sedimentation in relation to the front of the carbonate platform: from its slope, where the sedimentation rate was extremely high, to its more distant foreland showing slightly deeper and quieter conditions, and slower sedimentation rate. In such circumstances the very small thickness of coeval deposits of the "oolitic formation" at Kodrab, generally confined to the carbonate platform area, appears an abnormal feature and needs an additional explanation.

The same feature of very small thickness of particular rock units in the Kodrab succession is observed also among the younger deposits. The overlaying units $2-6$ of the Kodrab succession, as observed in the Rogaszyn Quarry, consist of alternating rock bodies of marls and micritic limestones of mudstone type with marly intercalations, generally very poor in benthic fauna, and attaining $\sim 9 \mathrm{~m}$ in thickness. They represent some middle and upper parts of the Platynota Zone, and correspond to the Skowronów Limestone Member (with the Zapole Marly Bed at the base), and the Góry Marly Member of the Prusicko Formation in the Wielun Upland, attaining a total thickness of $\sim 55-65 \mathrm{~m}$. A local development of units 7 and 8 in the Rogaszyn Quarry succession resulted possibly from synsedimentary movements of the fault block that formed gentle sea-floor elevations, where some deposits enriched in ammonite shells were deposited. The ammonites prove the age of synsedimentary movements near the boundary of the Platynota and Hypselocyclum chrons.

The deposits overlaying the main omission surface at Kodrab (Rogaszyn Quarry) are represented by the biodetrital limestones with common bivalve fauna, and oncolites at the top (unit 9), $\sim 10 \mathrm{~m}$ in thickness. They correspond to the lower part of the Hypselocyclum Zone (mostly the lussanense horizon). The deposits of the same age at the eastern and northern borders of the Wielun Upland are represented by chalky limestones with abundant benthic fauna, such as sponges (siliceous and calcareous), serpulids, bryozoans, bivalves and the hermatypic corals Microsolenidae, and have been distinguished as the Kule Limestone Member of the Prusicko Formation, attaining from at least $40 \mathrm{~m}$ up to $>100 \mathrm{~m}$ in thickness. These chalky limestones are replaced laterally at the northern border of the Wielun Upland by the biodetrital chalky limestones with common hermatypic corals, and locally with oolites. They represent unit A of the "oolitic formation" and attain at least $~ 90-120 \mathrm{~m}$ in thickness (Wierzbowski, 2017). The approximately coeval deposits to those discussed above at the northwestern border of the Holy Cross Mts. are recognized as the "upper Kurnędz limestone member" $\left(D_{2}\right.$ member) of the "oolitic formation". This member consists of different biodetrital and oolitic limestones with common marly intercalations, especially in its lowermost and middle parts; it attains from $\sim 45$ to $60 \mathrm{~m}$ in thickness (Matyja and Wierzbowski, 2014). The corresponding stratigraphical interval in the Betchatów Geo-2a core is represented by marly limestones and locally oolites below, 14 m thick (depth 298-312 m), and the overlying microoncolitic and/or oolitic limestones with common fauna, such as Trichites and nerineid gastropods, at least $40 \mathrm{~m}$ thick (depth 258-298 m).

Similar differences in thicknesses between some younger rock units at Kodrab and the coeval deposits of the neigbouring areas are also seen in the upper parts of the successions. The yellowish brittle marls of unit 10 attaining at Kodrab, in the Rogaszyn Quarry section, $~ 3.5 \mathrm{~m}$ in thickness may be correlated with the well-developed marly unit of the northern border of the Wieluń Upland succession - the Kiełczygłów Marl Mem- ber of the Burzenin Formation (or unit B of the "oolitic formation"). The unit attains there $\sim 22-30 \mathrm{~m}$, but locally even $45 \mathrm{~m}$, in thickness (Wierzbowski, 2017). The coeval member $D_{3}$, in the northwestern border of the Holy Cross Mts. consists also of marls with subordinate marly limestone intercalations. Its thickness ranges between 22 and $37 \mathrm{~m}$ (Matyja and Wierzbowski, 2014).

The overlying oolitic limestones (unit 11, Oolite of Smotryszów) are generally poorly exposed in the Rogaszyn Quarry section and their thickness cannot be precisely estimated - it may range up to $\sim 10 \mathrm{~m}$. The deposits correspond to some upper parts of the Hippolytense Subzone, possibly up to the lower part of the Lothari Subzone of the Hypselocyclum Zone. The coeval deposits at the northern border of the Wielun Upland, corresponding to units $\mathrm{C}-\mathrm{F}$ of the "oolitic formation", show generally similar facies development, but attain $\sim 100-110 \mathrm{~m}$ in thickness. On the other hand, the deposits from the northwestern border of the Holy Cross Mts., corresponding to unit $D_{4}$ of the "oolitic formation" and showing very close facies development, attain a slightly larger thickness (22-30 m, locally up to $\sim 43 \mathrm{~m}$ ) as compared with those in the Rogaszyn Quarry of the Kodrąb succession.

\section{DISCUSSION}

The overall character of the deposits of the "oolitic formation" in the Kodrab succession and their stratigraphical position show that the shallow-water carbonate platform prograded in this area rather early during the Early Kimmeridgian, at least during the Planula Chron (or maybe even earlier), and remained here until the Hypselocyclum Chron. This may be related to the activity of the generally WNW-ESE-trending tectonic zone being the prolongation of the Holy Cross lineament towards the west, which uplifted the areas located north of it: from the northwestern border of the Holy Cross Mts., through the Radomsko elevation area, and further west to some parts at the northern border of the Wielun Upland (see Matyja and Wierzbowski, 2014; Wierzbowski, 2017). The special character of deposits of the Kodrab succession discussed above indicates, however, that their sedimentation was additionally controlled by synsedimentary tectonic movement of a separate fault block. Judging from the difference in thickness of the deposits as compared with those in the neighbouring areas, the Kodrab area (Rogaszyn Quarry) seems to have belonged to a separate fault block especially active from the latest Planula Chron until the beginning of the Hypselocyclum Chron during the Early Kimmeridgian. The fault responsible for the formation of the deposits at Kodrab could represent a fragment of the special system of faults trending generally NW-SE (see Fig. 1) as recognized previously at the northwestern border of the Holy Cross Mts. (Matyja and Wierzbowski, 2014). A similar fault system occurs at the boundary between the Wielun Upland and the Częstochowa Upland (Matyja and Wierzbowski, 2016), and its activity during the Early Kimmeridgian has been well-proved by ammonites and analysis of a dinocyst assemblages recognized in the infillings of the neptunian dykes related to these faults (Barski, 2012). These faults could represent the prolongation of the so-called Grójec Fault system active already in the Late Paleozoic (Matyja and Wierzbowski, 2014; cf. also e.g. Aleksandrowski and Buła, 2017; Krzywiec, 2017).

Although the westward prolongation of the deep tectonic zone of the Holy Cross lineament onto the areas located towards the west, including the Radomsko elevation area, is commonly assumed (see, e.g., Pożaryski, 1971; Głazek, 1999; 
Głazek et al., 2015), the detailed position of this tectonic zone in the study area is difficult for determination. It should be situated, however, rather close to the areas of the Oligocene-Miocene graben structures, like the Kleszczów Graben, which seems to be related also to the activity of the tectonic zone in question. This assumption is strongly supported by, the direct relation between the development of these young graben structure (proved in some areas) and the distribution of the particular facies types controlled by synsedimentary tectonic movements in their Upper Jurassic substrate (see Krajewski et al., 2016). If such position of the tectonic zone has been accepted, the general continuation of this tectonic zone being the prolongation of the Holy Cross lineament should be crosscut by the supposed NW-SE-stretching prolongation of the Grójec Fault system at the Radomsko elevation. The crossing of the two tectonic zones in the deep substrate could be attributed markedly to the formation of the Radomsko elevation during the Laramian movements.

The occurrence of three main marly units, distinguished originally as the lower, middle, and upper marly units in the Wieluń Upland (Wierzbowski, 1966), and recognized recently as the Latosówka Marl Mbr., the Góry Marl Mbr. (and the Zapole Marl Bed occurring below at the base of the Skowronów Limestone Mbr.), and the Kiełczygłów Marl Mbr., as well as their wide lateral distribution in successions representing the different environmental conditions from the margins of the Holy Cross Mts. to the Wieluń Upland (see Fig. 2 and Table 1), suggest that their appearance was controlled by the tectonic events, but possibly superimposed on climatic cycles (Wierzbowski, 2017). It is highly probable that the appearance, at the end of the Planula Chron, of the lowermost of them - the Latosówka Marl Member, characterized by a marked input of siliciclastic material - was controlled mainly by the tectonic activity. The occurrence of younger marly units seems to be controlled mostly by the climatic conditions, although some tectonic activity during formation of the youngest of them may also be considered (Wierzbowski, 2017).

The youngest deposits in the Kodrab succession, corresponding to the upper part of the Lower Kimmeridgian (including deposits of the "platy limestones and underlying clays of Dmenin" after Kutek, 1968; and possibly unit 12 herein), do not already show any marked differences in facies development and in thickness as compared with coeval deposits known from adjoining areas. The wide appearance of similar bedded lime- stones and marls with ammonites, corresponding to the Burzenin Formations, suggests a generally deeper-water depositional environment. This phenomenon resulted from the uniform subsidence of the whole area at least between the Wielun Upland and the northwestern margin of the Holy Cross Mts. during the late Hypselocyclum Chron, and, in consequence, the disappearance of the shallow-water carbonate platforms in these areas (e.g., Wierzbowski, 2017).

\section{CONCLUSIONS}

The detailed biostratigraphical classification of the Lower Kimmeridgian succession at Kodrąb, Radomsko elevation, central Poland, revealed the presence of the Platynota and Hypselocyclum ammonite zones and several lower-rank units (subzones, horizons), making detailed chronostratigraphical correlation possible with successions from the adjoining areas.

Although the deposits of the succession studied represent the shallow-water "oolitic formation", their thickness is markedly smaller (generally representing only 15-20\%) as compared with that of coeval deposits of the same facies zone in other areas, such as the northern border of the Wielun Upland, and the NW margin of the Holy Cross Mts.

The development of the shallow-water deposits of the carbonate platform, from the northwestern margin of the Holy Cross Mts., through the Radomsko elevation, and westward onto the present northern border of the Wielun Upland, was controlled during the Early Kimmeridgian by the activity of the generally WNW-ESE-trending tectonic zone, being the prolongation of the Holy Cross lineament (see Matyja and Wierzbowski, 2014; Krajewski et al., 2016; Wierzbowski, 2017). A markedly smaller thickness of the deposits and their facies development at Kodrab resulted from the activity of another, NW-SE-trending synsedimentary fault system - possibly the prolongation of the so-called Gójec Fault.

Acknowledgements. The study was supported (AW) by the National Science Centre, Poland (project No. 2014/13B/ST10/02511), and (EG) by the Faculty of Geology, University of Warsaw (project No. BSt 170202). We are grateful to the journal referees for their critical reviews of the manuscript.

\section{REFERENCES}

Aleksandrowski, P., Buła, Z., 2017. Struktury późnopaleozoiczne (waryscyjskie) 1:5000 000 (in Polish). In: Atlas Geologiczny Polski (eds. J. Nawrocki and A. Becker): 43. Państwowy Instytut Geologiczny - PIB, Warszawa.

Atrops, F., 1982. Le sous familie des Ataxioceratinae (Ammonitina) dans le Kimméridgien inférieur du sud-est de la France. Systématique, evolution, chronostratigraphie des genres Orthosphinctes et Ataxioceras. Documents des Laboratoires de Géologie Lyon, 83: 1-463.

Barski, M., 2012. Dinoflagellate cysts from neptunian dykes in the Middle Jurassic of Poland - a stratigraphical approach. Review of Palaeobotany and Palynology, 169: 38-47.

Czubla, P., 1988. Tectonics of the Radomsko Elevation on the basis of mesostructural methods (in Polish with English summary). Przegląd Geologiczny, 36: 560-566.
Dadlez, R., Marek, S., Pokorski, J., 2000. Geological map of Poland without Cainozoic deposits, scale 1:1 000 000. Państwowy Instytut Geologiczny, Warszawa.

Dembowska, J., 1979. Systematization of lithostratigraphy of the Upper Jurassic in northern and central Poland (in Polish with English summary). Kwartalnik Geologiczny, 23 (3): 617-630.

Geyer, O.F., 1961. Monographie der Perisphinctidae des unteren Unterkimeridgium (Weisser Jura $\gamma$, Badenerschichten) im süddeutschen Jura. Palaeontographica, 117A: 1-157.

Głazek, J., 1999. Transpresyjno-solna geneza struktury Wielunia (in Polish). In: Młodoalpejski rów Kleszczowa: rozwój i uwarunkowania w tektonice regionu. XX Konferencja Terenowa Sekcji Tektonicznej P.T. Geol.: 69-76. 
Głazek, J., Dąbrowski, P., Ratajczak, R., 2015. Objaśnienia do Szczegółowej Mapy Geologicznej Polski 1:50 000, arkusz Wieluń (in Polish). Państwowy Instytut Geologiczny - PIB, Warszawa.

Gutowski, J., Wierzbowski, A., Złonkiewicz, Z., 2006. Bukowa, large limestone quarry (Upper Oxfordian-lowermost Kimmeridgian). In: Jurassic of Poland and adjacent Slovakian Carpathians (eds. A. Wierzbowski et al.): 188-190. Field trip guidebook: 7th International Congress of the Jurassic System, 6-18 September 2006, Kraków, Poland. Polish Geological Institute, Warszawa.

Jaworowski, K., 1962. Jura w zachodniej części rygla przedborskiego (in Polish). Przeglad Geologiczny, 10: 46-47.

Karczewski, L., 1965. Fauna and stratigraphy of the Malm in the vicinity of Radomsko (Central Poland) (in Polish with English summary). Biuletyn Instytutu Geologicznego, 192: 97-146.

Krajewski, M., Olchowy, P., Felisiak, I., 2016. Late Jurassic facies architecture of the Złoczew Graben: implications for evolution of the tectonic-controlled northern peri-Tethys shelf (Upper Oxfordian - Lower Kimmeridgian). Facies, 62: 3-19.

Krzywiec, P., 2017. Przekrój sejsmiczny przez strefę uskokową Grójca (in Polish). In: Atlas Geologiczny Polski (eds. J. Nawrocki and A. Becker): 42. Państwowy Instytut Geologiczny PIB, Warszawa.

Kutek, J., 1968. The Kimmeridgian and uppermost Oxfordian in the SW margins of the Holy Cross Mts. (Central Poland). Part I. Stratigraphy (in Polish with English summary). Acta Geologica Polonica, 18: 494-586.

Łuniewski, A., 1947. Notes on geology in the vicinity of Radomsko (in Polish with English summary). Biuletyn Państwowego Instytutu Geologicznego, 38: 9-21.
Matyja, B.A., Wierzbowski, A., 2014. Upper Jurassic of the Tomaszów syncline (in Polish with English summary). In: Jurajskie utwory synkliny tomaszowskiej. Jurassica XI. Przewodnik wycieczek terenowych, abstrakty i artykuły (eds. A. Feldman-Olszewska and A. Wierzbowski): 9-20. Państwowy Instytut Geologiczny - PIB, Warszawa.

Matyja, B.A., Wierzbowski, A., 2016. Jura górna (in Polish). In: Wody podziemne rejonu częstochowsko-zawierciańskiego ich występowanie, zagrożenie, degradacja i ochrona (ed. A. Pacholewski): 18-26. Informator PSH, Państwowy Instytut Geologiczny - PIB, Warszawa.

Mrozek, K., 1975. Budowa geologiczna struktur wgłębnych w południowej części synklinorium łódzkiego (in Polish). Wyd. Geol., Warszawa.

Pożaryski, W., 1971. The tectonics of the Radomsko Elevation (in Polish with English summary). Rocznik Polskiego Towarzystwa Geologicznego, 41: 169-179.

Schairer, G., 1974. Quantitative Untersuchungen an Perisphinctidae (Ammonoidea) des untersten Unterkimmeridgium der Fränkischen Alb (Bayern). Zitteliana, 3: 37-124.

Schneid, T., 1939, 1940. Über Raseniiden, Ringsteadiiden und Pictoniiden des nördlichen Frankenjura. Palaeontographica, 89 (1939): 117-184; 91 (1940): 79-119.

Wierzbowski, A., 1966. L'Oxfordien supérieur et le Kimméridgien inférieur du Plateau de Wieluń (in Polish with French summary). Acta Geologica Polonica, 16: 127-200.

Wierzbowski, A., 2017. The Lower Kimmeridgian of the Wieluń Upland and adjoining regions: lithostratigraphy, ammonite stratigraphy (upper Planula/Platynota to Divisum zones), palaeogeography and climate-controlled cycles. Volumina Jurassica, 15: 41-120. 